\title{
A Knowledge-based Approach in the Conceptualisation of Disease Terms in Tiv for a More Effective Health Communication
}

\author{
Bem P. lanna \\ Nasarawa State University, Nigeria
}

\begin{abstract}
There is a general perception that terminology constitutes an intractable obstacle to the use of African languages in highfunction domains such as science and technology, engineering, medicine, etc. It is with a view to enhancing specificity which facilitates better communication that one of such domains (health) was chosen for this study. Specifically, the study looked at cases of semantic extensions and mismatches that lead to vagueness medical discourse in Tiv speakers (Tiv, a language spoken in
\end{abstract}

\footnotetext{
Bem P. Ianna

Department of Languages and Linguistics, Nasarawa State University,

P.M.B 1022, Keffi, NIGERIA

Email: bemianna500@gmail.com
}

Received 8 August, 2017; Revised 3 September, 2017; Accepted 13 September, 2017

Copyright ( 92017 Language Research Institute, Sejong University

Journal of Universal Language is an Open Access Journal. All articles are distributed online under the terms of the Creative Commons Attribution Non-Commercial License (http://creativecommons.org/licenses/by-nc/3.0) which permits unrestricted non-commercial use, distribution, and reproduction in any medium, provided the original work is properly cited. 
62 A Knowledge-based Approach in the Conceptualisation of Disease Terms in

Benue, Taraba, and Nasarawa States of Nigeria). Focus group discussions and translation exercise were employed to carry out the study which revealed, as expected, cases of semantic extensions and mismatches in the discourse of the research subjects. For example, cases of semantic extensions were noticed when preclinical students conceptualised diseases through the use of terms with narrower semantic coverage at some point, and wider coverage at another. Also cases of mismatch were seen. Both point to the imperative of engagement with disciplinary knowledge structures for the creation of better designations for concepts leading to greater clarity.

Keywords: terminology, conceptualisation, diseases, communication, knowledge structures

\section{Introduction}

With the realisation that concepts are central to the success of communication, efforts have been made by various authors to shed light on what concepts are and how useful they are in communication (Novak \& Gowin 1984, Thagard 1992, Novak 1998, Robinson 1999, Kinchin, Hay \& Adams 2000, and so on). An understanding of concept relations or concept maps, for instance, equips language users with better understanding of how terms are interconnected and organised in a given subject field. In any work on terminology it is, therefore, imperative to have an understanding of issues like what a concept is, what concept relations and concept maps are. This is because of the intertwined relationship that exists between a term and a concept.

Thagard (1992: 21) describes concepts as mental structures representing what words stand for. He continues that concepts are normally products of ideas and thoughts that are like images, with some of these ideas are innate, some deriving from external source, 
and others being constructed by the thinker. These ideas and thoughts are linguistic entities given through definitions. As humans, we try to give definitions to linguistic entities as a result of the need for consciousness to develop a grasp of truth through a dialectal process of analysing the structural components of such complex entities. Antia (2000) postulates that concept is a mental representation, reduction or (re)interpretation of reality that is perceptible or that was previously non-existent.

Concepts can be explained by using concept maps - diagrams that represent organised knowledge (Novak \& Gowin 1984). In other words, they are graphical representations of knowledge that consist of concepts and the relationships between them. Concept maps generally attempt to represent concretely human knowledge of terms or concepts and the semantic relationships among these terms. Developers and users of concept maps argue that concept maps can offer some insight into (students') understanding (Novak \& Gowin 1984; Ghaye \& Robinson 1989; Schmid \& Telaro 1990; Mintzes, Wandersee \& Novak 1998; Novak 1998; Robinson 1999). Their argument is that concept maps help learners integrate new knowledge built upon their existing naïve concepts. An important function of the map, as explained by Kinchin, Hay \& Adams (2000), for example, is to help make the overall framework of the concept explicit. This, they say, is particularly important for complex tasks where people undertaking such tasks display a fragmentary understanding and are frequently unable to integrate all the components to form a meaningful overview. Sager's (1990) example of a concept map can be seen in Figure 1.

This tree diagram in Figure 1 shows that one thing is a part of a whole. For instance, 'physics', 'chemistry', and 'biology' are parts of the whole 'natural sciences'. In the same way, the 'physics' that was 
64 A Knowledge-based Approach in the Conceptualisation of Disease Terms in

Figure 1. An Illustration of Partitive Relationship (Adapted from Sager 1990: 32)

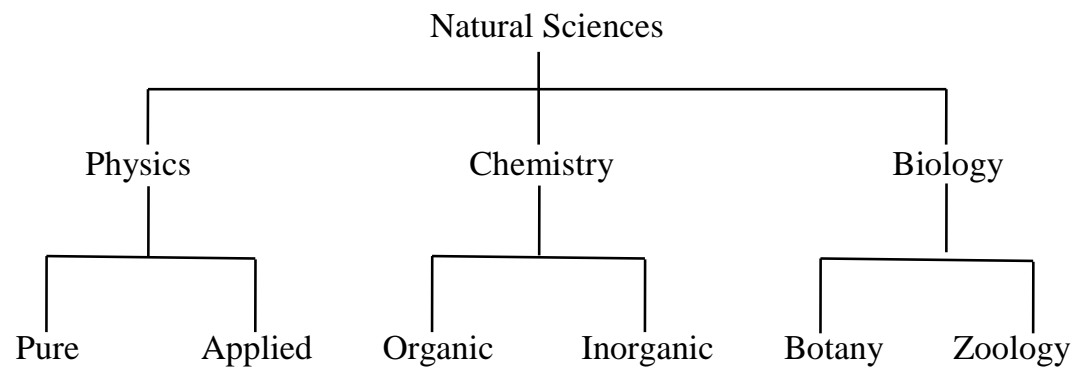

a part at a point has become a whole at another point and 'pure' and 'applied' has become its parts. The same can be seen with 'chemistry' and 'biology'. These conceptual relations are fundamental to the organisation of terms because the hierarchies generated by such relations will help in understanding how terms will be organised in the terminology of any given field. For instance, knowledge of the class associations that exist amongst concepts will show that terms are not created arbitrarily; their creation follows conventions. In the same way, terms are related by explanatory links. This, therefore, means that conceptual understanding - the type that calls for higher-order thinking - will be very useful in terminological interventions.

\section{The Effects of Conceptualisation/Communication on Healthcare Delivery}

Conceptualisation plays a vital role in our communication processes, and communication on its part is an integral element of human existence. This explains why Hammond (2017) says that 
communication as an essential component of human co-existence thrives on a combination of processes of operational communication such as access to channels of communication, tools for information dissemination, and the availability of feedback mechanisms which serve effectively to negotiate and persuade one another in a discourse environment, and this cuts across all disciplines. The manner in which we communicate has a direct bearing on the manner in which the recipients of our communication respond. It is as a result of the importance in human existence that communication in the area of bio-medicine has, for some time, received serious attention.

Researchers, over the years, have addressed the issue of healthcare language (Crawford, Brown \& Nolan 1998; Yassin \& Antia 2003; Keally, Smith \& Winser 2004; Soergel, Tse \& Slaughter 2004; Levin 2006; Antia \& Razum 2012).

Yassin \& Antia (2003) in a study on language and compromised ethics report that there are some elements of compromising health quality on linguistic grounds. In another study that supports this position, Antia \& Bertin (2004: 108) quote John Sinclair as saying that "people who speak simple English have simple diseases". Doctors who responded to their questions on whether language could improve the quality of diagnosis responded in the affirmative with $76 \%$. In another study by Soergel, Tse \& Slaughter (2004) which centered on how healthcare consumers need to find, comprehend, and interpret health information revealed that mismatches in representation of health information used by consumers and professionals occur at different levels of knowledge representation, such as terminology (i.e., form or surface structure and concept or meaning) and semantic relationships. The study suggests that consumers' ability to identify terms to describe their needs, finding, and understanding relevant information helps in applying such 
66 A Knowledge-based Approach in the Conceptualisation of Disease Terms in

knowledge in (informal) healthcare decision making. Levin (2006) in his study found that differences in the definitions of medical terminology by patients and doctors could cause miscommunication, and this could affect healthcare delivery. The study showed that parents who took their children to the hospital experienced difficulty in understanding terms used by doctors and words in common use were understood differently by these two groups. He reports that most Xhosa words were not in the doctors' vocabulary, and some common English words were not in the parents' vocabulary. Where words were in the vocabulary of both groups, significant differences existed in the number and range of definitions, with many clinically significant discordances of definition being apparent. Antia \& Razum (2012) in their study have particularly investigated modeling success in HIV/AIDS messaging in two countries - Germany and Nigeria. In the study, they found that HIV/AIDS messaging is notoriously difficult in part because of the diversity of disciplines interested in the area (e.g., disciplines like public health, psychology, communication, education, sociology, linguistics) and the claims made in each, often on the basis of coming-to-known processes. They argue that although relevant research in public health and communication emphasises audience responses to messages but sometimes slights analyses of the texts of these messages, work in (applied) linguistics tends to engage with texts without, however, framing its claims in the contexts. This gives room for discordance in understanding the messages. Clarity of expression facilitates better understanding, and it also saves time in healthcare delivery.

One of the problems Tiv speakers have is conceptualising disease terms in such a way that will make meaning when they are reporting their health conditions to health care providers. This naturally affects the kind of understanding that is required between/among 
participants in the discourse (health care providers and seekers). It is an effort to exemplify such wrong conceptualisations and suggest how best to conceptualise such disease terms for a more effective communication that this study was carried out.

\section{Methods}

Our data sources for this study were two: focus group discussions (FGD) and a translation exercise. A focus group is a special type of group discussion with a narrowly focused topic discussed by group members of equal status (Payne \& Payne 2004). The FGD has the advantage of allowing to get as close as possible to the real-life situations where people discuss, formulate, and modify their views and make sense of their experiences as in peer group or professional teams.

In each of the discussion groups, ten diseases were selected. These diseases were selected on the basis of their prevalence in the area covered by the research. The research subjects were familiar with them. The focused group discussions were audio-taped and transcribed for analysis. In the translation exercise, the list of ten diseases already mentioned in the focus group discussions was given to physicians to translate. This instrument was used to validate/invalidate the information that was elicited via the first instrument.

These two data sources helped us see: (i) how Tiv patients conceptualised their illnesses via data source 1, and (ii) data source 2 enabled us see, via conceptual maps issues relating to matches and mismatches. This showed us where we need to intervene (reclassification of terms, restriction/extension of the scope of terms, 
68 A Knowledge-based Approach in the Conceptualisation of Disease Terms in

change of slots in hierarchy, changes in collocations and ultimately, relexicalisation of concepts).

\section{Research Population}

For the focus group discussions with the laymen, eight people were used for this discussion in each of the Local Government Areas (LGAs) covered by the research. The instruments for eliciting data were used in selected villages and hospitals spread across four (4) out of the fourteen (14) Tiv-speaking LGAs of Benue State. The four LGAs were selected in such a way as to achieve geographical spread (two LGAs from each of the two senatorial districts in the Tiv nation) while the four hospitals were selected randomly. The LGAs were Katsina-Ala, Kwande, Buruku, and Makurdi. Eight people were preferred so as to have a controllable size. In the focus group discussions with the pre-clinical students, eight out of seventeen students were used and eight students out of fourteen were used in the discussion with clinical students. It was felt that eight students were a good representation of the total number of students. As for the translation exercise, a physician in each of the four General Hospitals (in the four LGAs mentioned above), and four at the Benue State University Teaching Hospital were asked to translate the list of diseases in Tiv. The number of physicians available in a hospital determined the number chosen for the translation exercise.

The participants in this research were selected on the following basis: (i) people who were native speakers of Tiv and who were balanced bilinguals of Tiv and English, and (ii) native speakers of Tiv with some competence in English. Under this criterion, educated people were preferred in order to avoid the problem of participants 
finding it too difficult to comprehend some English terms for diseases.

\section{Data Collection and Analysis Procedure}

\subsection{Data Types and Collection}

Two types of data: discourse-inflected data from the focus group discussions and the intuition of each subject and their competence levels from the translation exercise were generated as discussed below.

\section{1) Data Type 1}

Data type 1 was generated via data source 1 (focus group discussions). Here, discussions were organised for two sets of people: educated laymen with no minimal expertise and medical students.

i. For the laymen, discussions were tailored towards getting them talk about diseases. The researcher moderated these discussions so as to get the subjects talk about these diseases and their symptoms.

ii. In the second group, medical students in the Benue State University Teaching Hospital (BUTH), Makurdi were also engaged to talk about diseases in Tiv. Discussions were organised for:

- Medical students at the pre-clinical level, and

- students who are well advanced in their studies (clinical students). 
70 A Knowledge-based Approach in the Conceptualisation of Disease Terms in

To elicit data here, experimental subjects were engaged in discussions concerning the same diseases that were discussed by laymen. Attention was paid to the differences in the subjects' knowledge of the distinctiveness and the relational systems of those diseases at their pre-clinical level of study and then at the clinical level. This gave some insight into the subjects' conceptions of the diseases.

\section{2) Data Type 2}

Data type 2 was generated via data source 2 (translation exercise). The translations sought to establish the logic and meaning classification in this health discourse. From the physicians' translations, one could see if there were such features of overextensions, under-extensions, overlaps, mismatches in the laymen's conceptualisations.

\subsection{Data Analysis Procedure}

Data obtained from each of the data sites (focus group discussions with the laymen and medical students and translation exercise from the physicians) were analysed independently. Conceptualisations and lexicalisation of Tiv terms for diseases and descriptions of these diseases from the standpoint of equivalent relations, mismatches, over-/under-extensions, and so on were analysed. The analysis revealed cases of differences in the knowledge structures underlying and complicating communication between laymen and specialists. 


\section{Data Presentation}

Tables 1-4 present the results of the focus group discussions with the laymen, while tables 5 and 6 present results of focus group discussions with pre-clinical and clinical students respectively. Table 7 presents the data obtained from the translation exercise done by physicians.

Table 1. Names and Descriptions of Diseases by Laymen in Katsina-Ala L.G.A.

\begin{tabular}{|c|c|c|c|}
\hline & $\begin{array}{l}\text { Names of Diseases } \\
\text { in English }\end{array}$ & $\begin{array}{l}\text { Laymen's Names } \\
\text { for them in Tiv }\end{array}$ & $\begin{array}{c}\text { Symptoms as Given } \\
\text { by Laymen }\end{array}$ \\
\hline 1. & Glaucoma & Apolo & $\begin{array}{l}\text { Discharging of the } \\
\text { eyes; pains in the eyes }\end{array}$ \\
\hline 2. & Cataract & Apolo & $\begin{array}{l}\text { Discharging of the } \\
\text { eyes; pains in the eyes }\end{array}$ \\
\hline 3. & $\begin{array}{l}\text { Dilated Heart } \\
\text { Disease }\end{array}$ & $\begin{array}{l}\text { Angev mbu ishima } \\
\text { (heart disease) }\end{array}$ & Pains in the heart area \\
\hline 4. & $\begin{array}{l}\text { Hypertrophic } \\
\text { Heart Disease }\end{array}$ & $\begin{array}{l}\text { Angev mbu ishima } \\
\text { (heart disease) }\end{array}$ & Pains in the heart area \\
\hline 5. & $\begin{array}{l}\text { Restrictive Heart } \\
\text { Disease }\end{array}$ & $\begin{array}{l}\text { Angev mbu ishima } \\
\text { (heart disease) }\end{array}$ & Pains in the heart area \\
\hline 6. & Jaundice & Myamkyule & $\begin{array}{l}\text { High body temperature; } \\
\text { yellowish eyes }\end{array}$ \\
\hline 7. & Yellow Fever & Myamkyule & $\begin{array}{l}\text { High body temperature; } \\
\text { yellowish eyes }\end{array}$ \\
\hline 8. & Gastric Ulcer & $\begin{array}{l}\text { Avav shin uya } \\
\text { (wounds in the stomach) }\end{array}$ & Stomach pains \\
\hline 9. & Duodenal Ulcer & $\begin{array}{l}\text { Avav shin uya } \\
\text { (wounds in the stomach) }\end{array}$ & Stomach pains \\
\hline 10. & AIDS & $\begin{array}{l}\text { Anakande } \\
\text { (who emaciates) }\end{array}$ & Emaciation \\
\hline
\end{tabular}


72 A Knowledge-based Approach in the Conceptualisation of Disease Terms in

Table 2. Names and Descriptions of Diseases by Laymen in Buruku L.G.A.

\begin{tabular}{|c|l|l|l|}
\hline 1. & $\begin{array}{l}\text { Names of Diseases } \\
\text { in English }\end{array}$ & \multicolumn{1}{|c|}{$\begin{array}{c}\text { Laymen's Names } \\
\text { for them in Tiv }\end{array}$} & $\begin{array}{c}\text { Symptoms as Given } \\
\text { by Laymen }\end{array}$ \\
\hline \hline 2. & Cataract & Apolo & $\begin{array}{l}\text { Discharging of the } \\
\text { eyes; pains in the eyes }\end{array}$ \\
\hline 3. & $\begin{array}{l}\text { Dilated Heart } \\
\text { Disease }\end{array}$ & $\begin{array}{l}\text { Angev mbu ishima } \\
\text { (heart disease) }\end{array}$ & $\begin{array}{l}\text { Discharging of the } \\
\text { eyes; pains in the eyes }\end{array}$ \\
\hline 4. & $\begin{array}{l}\text { Hypertrophic Heart } \\
\text { Disease }\end{array}$ & $\begin{array}{l}\text { Angev mbu ishima } \\
\text { (heart disease) }\end{array}$ & Pains in the heart area \\
\hline 5. & $\begin{array}{l}\text { Restrictive Heart } \\
\text { Disease }\end{array}$ & $\begin{array}{l}\text { Angev mbu ishima } \\
\text { (heart disease) }\end{array}$ & Pains in the heart area \\
\hline 6. & Jaundice & Myamkyule & $\begin{array}{l}\text { High body temperature; } \\
\text { yellowish eyes }\end{array}$ \\
\hline 7. & Yellow Fever & Myamkyule & $\begin{array}{l}\text { High body temperature; } \\
\text { yellowish eyes }\end{array}$ \\
\hline 8. & Gastric Ulcer & $\begin{array}{l}\text { Avav shin uya } \\
\text { (wounds in the stomach) }\end{array}$ & Stomach pains \\
\hline 9. & Duodenal Ulcer & $\begin{array}{l}\text { Avav shin uya } \\
\text { (wounds in the stomach) }\end{array}$ & Stomach pains \\
\hline 10. & AIDS & $\begin{array}{l}\text { Anakande } \\
\text { (who emaciates) }\end{array}$ & Emaciation \\
\hline
\end{tabular}

Table 3. Names and Descriptions of Diseases by Laymen in Kwande L.G.A.

\begin{tabular}{|c|l|l|l|}
\hline \multicolumn{1}{|c|}{$\begin{array}{c}\text { Names of Diseases } \\
\text { in English }\end{array}$} & \multicolumn{1}{|c|}{$\begin{array}{c}\text { Laymen's Names } \\
\text { for them in Tiv }\end{array}$} & $\begin{array}{c}\text { Symptoms as Given } \\
\text { by Laymen }\end{array}$ \\
\hline \hline 1. & Glaucoma & Apolo & $\begin{array}{l}\text { Discharging of the } \\
\text { eyes; pains in the eyes }\end{array}$ \\
\hline 2. & Cataract & Apolo & $\begin{array}{l}\text { Discharging of the } \\
\text { eyes; pains in the eyes }\end{array}$ \\
\hline
\end{tabular}




\begin{tabular}{|c|l|l|l|}
\hline 3. & $\begin{array}{l}\text { Dilated Heart } \\
\text { Disease }\end{array}$ & $\begin{array}{l}\text { Angev mbu ishima } \\
\text { (heart disease) }\end{array}$ & Pains in the heart area \\
\hline 4. & $\begin{array}{l}\text { Hypertrophic Heart } \\
\text { Disease }\end{array}$ & $\begin{array}{l}\text { Angev mbu ishima } \\
\text { (heart disease) }\end{array}$ & Pains in the heart area \\
\hline 5. & $\begin{array}{l}\text { Restrictive Heart } \\
\text { Disease }\end{array}$ & $\begin{array}{l}\text { Angev mbu ishima } \\
\text { (heart disease) }\end{array}$ & Pains in the heart area \\
\hline 6. & Jaundice & Myamkyule & $\begin{array}{l}\text { High body temperature; } \\
\text { yellowish eyes }\end{array}$ \\
\hline 7. & Yellow Fever & Myamkyule & $\begin{array}{l}\text { High body temperature; } \\
\text { yellowish eyes }\end{array}$ \\
\hline 8. & Gastric Ulcer & $\begin{array}{l}\text { Avav shin uya } \\
\text { (wounds in the stomach) }\end{array}$ & Stomach pains \\
\hline 9. & Duodenal Ulcer & $\begin{array}{l}\text { Avav shin uya } \\
\text { (wounds in the stomach) }\end{array}$ & Stomach pains \\
\hline 10. & AIDS & $\begin{array}{l}\text { Anakande } \\
\text { (who emaciates) }\end{array}$ & Emaciation \\
\hline
\end{tabular}

Table 4. Names and Descriptions of Diseases by Laymen in Makurdi L.G.A.

\begin{tabular}{|c|l|l|l|}
\hline 1. & $\begin{array}{l}\text { Names of Diseases } \\
\text { in English }\end{array}$ & \multicolumn{1}{|c|}{$\begin{array}{c}\text { Laymen's Names } \\
\text { for them in Tiv }\end{array}$} & $\begin{array}{c}\text { Symptoms as Given } \\
\text { by Laymen }\end{array}$ \\
\hline \hline 2. & Cataract & Apolo & $\begin{array}{l}\text { Discharging of the } \\
\text { eyes; pains in the eyes }\end{array}$ \\
\hline 3. & $\begin{array}{l}\text { Dilated Heart } \\
\text { Disease }\end{array}$ & $\begin{array}{l}\text { Angev mbu ishima } \\
\text { (heart disease) }\end{array}$ & $\begin{array}{l}\text { Discharging of the } \\
\text { eyes; pains in the eyes }\end{array}$ \\
\hline 4. & $\begin{array}{l}\text { Hypertrophic Heart } \\
\text { Disease }\end{array}$ & $\begin{array}{l}\text { Angev mbu ishima } \\
\text { (heart disease) }\end{array}$ & Pains in the heart area \\
\hline 5. & $\begin{array}{l}\text { Restrictive Heart } \\
\text { Disease }\end{array}$ & $\begin{array}{l}\text { Angev mbu ishima } \\
\text { (heart disease) }\end{array}$ & Pains in the heart area \\
\hline 6. & Jaundice & Myamkyule & $\begin{array}{l}\text { High body temperature; } \\
\text { yellowish eyes }\end{array}$ \\
\hline
\end{tabular}


74 A Knowledge-based Approach in the Conceptualisation of Disease Terms in

\begin{tabular}{|c|l|l|l|}
\hline 7. & Yellow Fever & Myamkyule & $\begin{array}{l}\text { High body temperature; } \\
\text { yellowish eyes }\end{array}$ \\
\hline 8. & Gastric Ulcer & $\begin{array}{l}\text { Avav shin uya } \\
\text { (wounds in the stomach) }\end{array}$ & Stomach pains \\
\hline 9. & Duodenal Ulcer & $\begin{array}{l}\text { Avav shin uya } \\
\text { (wounds in the stomach) }\end{array}$ & Stomach pains \\
\hline 10. & AIDS & $\begin{array}{l}\text { Anakande } \\
\text { (who emaciates) }\end{array}$ & Emaciation \\
\hline
\end{tabular}

\subsection{A Discussion of the Data from the Laymen's Focus Group Discussion}

Consistent with our motivation that the framing of knowledge change might be applicable to and inform terminology development, we will discuss the data above (elicited from laymen). If we consider, as an example, the conceptualisation of diseases listed in tables 1-4 by laymen, varying degrees of non-equivalence between terms for Tiv health conditions and English terms would be seen. For example, a Tiv layman would generalise both 'gastric ulcer' and 'duodenal ulcer' to mean avav shin uya (wounds in the stomach) (cf. numbers 8 and 9 in tables 1-4). The laymen's term for these is also a mismatch. The users of the Tiv term: ôsa which is an adaptation of 'ulcer', do not know that 'ulcer' in English is a generic term used beyond lesions on the intestine: it also covers lesions on the skin. Another example of a mismatch is also found in Tiv laymen's speeches. For example, when the laymen talked of an eye problem and say they are suffering from apolo ${ }^{l}$ which is just caused by an infection and is

1 Etymologically, this appellation is from the US spaceship Apollo 11 which landed on the moon in 1969. This name was given to this disease by some Africans because many believed that it was brought from space that year. 
characterised by the reddening and discharge of the eyes, they may be suffering from a different disease entirely, for instance glaucoma or cataract.

Cases of under-differentiation could also be seen in numbers 3-5 in the four tables. Here, all the three heart diseases (dilated heart disease, restrictive heart disease, and hypertrophic heart disease) were rendered as angev mbu shima (heart disease). This is an example of using a generic term to cover all its sub-types. This shows a clear case of mismatch between an informed understanding of the different types of heart diseases and an uninformed understanding. Another example of overextension can be seen when the laymen conceptualised the dreaded disease 'acquired immune deficiency syndrome' (AIDS) as anakande (emaciate). The currency of this wrong conceptualisation among the laymen is as a result of one of the major symptoms of this disease: 'emaciation', but this is just one of many symptoms that this disease presents, and cannot be taken be a sign for this disease because many other diseases like diarrhea, ulcer, hepatitis, and so on also present with this symptom. In fact, many patients suffering from this disease do not show any sign of 'emaciation'. It is a general lack of knowledge about the disease that has led to this misconception about its lexicalisation. For instance, a better term for AIDS could be arrived at if the laymen knew more about the indications of the disease: collapse of the immune system, being incurable, etc. This may explain why other languages have better names for it. This is because such languages are more developed and have higher conceptual distinctiveness. For example, in Hausa it is 'Cuta mai karya gargumwarjiki' (a disease that breaks the shield of the body); in Yoruba it is 'Aarun ko gboogun' (a disease that defies treatment). In other words, a good dissection of the morphological components of 'Acquired Immune 
76 A Knowledge-based Approach in the Conceptualisation of Disease Terms in

Deficiency Syndrome' (or any other disease) will help to have a more concise idea of how such terms are formed and such knowledge could be of tremendous use for term conceptualisation in Tiv. In other words, the ability of the laymen to integrate all the components of AIDS to form a more meaningful overview of the disease will help them to lexicalise it better. A deep appreciation of the tremendous flexibility and descriptive power of the biomedical language in the creation of terms in Tiv is needed. Though, there may be some arguments (against the renditions other languages), especially in the direction of the disease not necessarily killing as the names in other languages suggest, an explanation would be that when the disease first broke out, it necessarily led to death unlike now.

\subsection{Conceptualisations of Pre-clinical Students}

As can be seen (in Table 5), in comparison with the conceptualisations of diseases by the pre-clinical students and those of the laymen, there is a marked difference in the conceptualisations of the pre-clinical students. For example, whereas the laymen conceptualised 'dilated heart disease', 'hypertrophic heart disease', and 'restrictive heart disease' in the same way, the pre-clinical students conceptualised them differently. The same thing goes for 'glaucoma'/'cataract', 'jaundice'/'yellow fever', and 'gastric ulcer'/'duodenal ulcer'. The differences noticed in the pre-clinical students' conceptualisations can be said to be as a result of the knowledge they have acquired in medical studies. 
Table 5. Pre-clinical Students' Conceptions of Diseases

\begin{tabular}{|c|c|c|c|}
\hline & $\begin{array}{l}\text { Names of Diseases } \\
\text { in English }\end{array}$ & $\begin{array}{l}\text { Pre-clinical Students' } \\
\text { Names for them in Tiv }\end{array}$ & $\begin{array}{l}\text { Symptoms as Given by } \\
\text { the Pre-clinical Students }\end{array}$ \\
\hline 1. & Glaucoma & $\begin{array}{l}\text { Ashe a nyoon } \\
\text { (eye pains) }\end{array}$ & $\begin{array}{l}\text { Eye pain; eye } \\
\text { reddening }\end{array}$ \\
\hline 2. & Cataract & $\begin{array}{l}\text { Ishange } \\
\text { (a substance that covers } \\
\text { part of the eye) }\end{array}$ & $\begin{array}{l}\text { A dark spot that covers } \\
\text { the ocular lens }\end{array}$ \\
\hline 3. & $\begin{array}{l}\text { Dilated Heart } \\
\text { Disease }\end{array}$ & $\begin{array}{l}\text { Ishima i kehen } \\
\text { (heart enlargement) }\end{array}$ & $\begin{array}{l}\text { Pains in the chest; } \\
\text { sleeplessness }\end{array}$ \\
\hline 4. & $\begin{array}{l}\text { Hypertrophic Heart } \\
\text { Disease }\end{array}$ & $\begin{array}{l}\text { Angev mbu yuhwan ken } \\
\text { ishima (heaviness in the } \\
\text { heart) }\end{array}$ & $\begin{array}{l}\text { Pains in the chest; } \\
\text { sleeplessness }\end{array}$ \\
\hline 5. & $\begin{array}{l}\text { Restrictive Heart } \\
\text { Disease }\end{array}$ & $\begin{array}{l}\text { Angev mbu yuhwan ken } \\
\text { ishima (heaviness in the } \\
\text { heart) }\end{array}$ & $\begin{array}{l}\text { Pains in the chest; } \\
\text { sleeplessness }\end{array}$ \\
\hline 6. & Jaundice & $\begin{array}{l}\text { Angev mbu sha mtema } \\
\text { (disease of the liver) }\end{array}$ & $\begin{array}{l}\text { High body temperature; } \\
\text { yellowish eyes }\end{array}$ \\
\hline 7. & Yellow Fever & $\begin{array}{l}\text { Myamkyule } \\
\text { (yellow fever) }\end{array}$ & $\begin{array}{l}\text { High body temperature; } \\
\text { yellowish eyes }\end{array}$ \\
\hline 8. & Gastric Ulcer & $\begin{array}{l}\text { Avav shin uya (lesions in } \\
\text { the stomach) }\end{array}$ & Stomach pains \\
\hline 9. & Duodenal Ulcer & $\begin{array}{l}\text { Avav shin uya (wounds } \\
\text { in the stomach) }\end{array}$ & $\begin{array}{l}\text { Pains in the lower part } \\
\text { of the abdomen; } \\
\text { stomach fullness }\end{array}$ \\
\hline 10. & AIDS & $\begin{array}{l}\text { Anakande } \\
\text { (who emaciates) }\end{array}$ & Emaciation \\
\hline
\end{tabular}

\subsection{Conceptualisations of Clinical Students}

Just like in the first two groups, experimental subjects in this category were also engaged in discussions concerning the same 
78 A Knowledge-based Approach in the Conceptualisation of Disease Terms in

diseases that were discussed by laymen and pre-clinical students. Here too, in relation to the first two groups, attention was paid to the subjects' knowledge of the distinctiveness and the relational systems of the diseases under study. The clinical students' renderings of these diseases are presented in Table 6.

Table 6. Clinical Students' Conception of Diseases

\begin{tabular}{|c|c|c|c|}
\hline & $\begin{array}{c}\text { Names of Diseases } \\
\text { in English }\end{array}$ & $\begin{array}{c}\text { Clinical Students' } \\
\text { Names for them in Tiv }\end{array}$ & $\begin{array}{l}\text { Symptoms as Given } \\
\text { by Clinical Students }\end{array}$ \\
\hline 1. & Glaucoma & $\begin{array}{l}\text { Mnyoon u igbila i ken } \\
\text { ashe (pains in the eye } \\
\text { nerves) }\end{array}$ & Pains in the eyes nerves \\
\hline 2 . & Cataract & Ishange & $\begin{array}{l}\text { The eye lens is covered } \\
\text { by a substance }\end{array}$ \\
\hline 3. & $\begin{array}{l}\text { Dilated Heart } \\
\text { Disease }\end{array}$ & $\begin{array}{l}\text { Ishima i mulan ken } \\
\text { imese (enlargement of } \\
\text { the heart on the left hand } \\
\text { side) }\end{array}$ & Palpitation; headache \\
\hline 4. & $\begin{array}{l}\text { Hypertrophic Heart } \\
\text { Disease }\end{array}$ & $\begin{array}{l}\text { Mmula u inyam i ken } \\
\text { ishima (swollen heart } \\
\text { muscle) }\end{array}$ & Palpitation; headache \\
\hline 5. & $\begin{array}{l}\text { Restrictive Heart } \\
\text { Disease }\end{array}$ & $\begin{array}{l}\text { Mtaver } u \text { kpekpe } u \\
\text { ishima (stiffening of the } \\
\text { heart walls) }\end{array}$ & Palpitation; headache \\
\hline 6. & Jaundice & $\begin{array}{l}\text { Angev mbu mlem } \\
\text { (a disease of the bile) }\end{array}$ & $\begin{array}{l}\text { High body temperature; } \\
\text { yellowish eyes }\end{array}$ \\
\hline 7. & Yellow Fever & $\begin{array}{l}\text { Myamkyule } \\
\text { (yellow fever) }\end{array}$ & $\begin{array}{l}\text { High body temperature; } \\
\text { yellowish eyes }\end{array}$ \\
\hline 8. & Gastric Ulcer & $\begin{array}{l}\text { Avav sha gwarmya u } \\
\text { vesen (lesions on the } \\
\text { large intestine) }\end{array}$ & $\begin{array}{l}\text { Pains in the lower part } \\
\text { of the abdomen; } \\
\text { stomach fullness }\end{array}$ \\
\hline
\end{tabular}




\begin{tabular}{|l|l|l|l|}
\hline 9. & Duodenal Ulcer & $\begin{array}{l}\text { Avav sha gwarmya } u \\
\text { kiriki (lesions on the } \\
\text { small intestine) }\end{array}$ & $\begin{array}{l}\text { Pains in the upper part } \\
\text { of the abdomen }\end{array}$ \\
\hline 10. & AIDS & $\begin{array}{l}\text { Angev mbu wuan ushoja } \\
\text { ken iyol (sickness that } \\
\text { kills antibiotics) }\end{array}$ & Emaciation \\
\hline
\end{tabular}

From Table 6, it could be seen that there are some degrees of divergence between the conceptualisations of the clinical students and those of the laymen and the pre-clinical students. For example, while the laymen rendered 'glaucoma' as apolo, the pre-clinical students render it as ashe a nyoon (eye pains), while the clinical students render it as mnyoon $u$ igbila $i$ ken ashe (pains in the eye nerves). One noticeable feature among these three groups is that there is a wider divergence of conceptualisation between the laymen and the pre-clinical/clinical students on the one hand and a convergence between the pre-clinical and the clinical students on the other hand. This can be explained. The latter, as a result of the knowledge they have acquired in the area of health, have a better understanding of what these diseases mean. The pre-clinical students, though yet to start full clinical studies are exposed to courses like: Human Anatomy, Human Physiology, Biochemistry, and Medical Microbiology. With the knowledge gained from such courses, they have a clearer understanding of the underlying structures of these diseases, and this informs their ability to conceptualise them better than the laymen.

Such a clearer relational distinctiveness is also noticed between the pre-clinical and clinical students. For example, while the pre-clinical students (as seen in number 3, Table 5) are general about their conceptualisation of 'dilated heart disease' the clinical students, in 
80 A Knowledge-based Approach in the Conceptualisation of Disease Terms in

number 3, Table 6 are more specific in their conceptualisation of the disease. While the pre-clinical students render it (in a general way) as ishima $i$ kehen (heart enlargement), the clinical students who are more advanced in medical studies render it in a more specific way as ishima $i$ mulan ken imese (enlarged heart in the left hand side). The rendition of the clinical students, to some extent, agree with that of the pre-clinical students in that both are pointing to the fact that it is a heart disease that is characterised by the enlargement of the heart. Where there is a difference is that the clinical students are more specific in their conceptualisation for being specific about the particular place where the enlargement takes place - the left hand side.

The differences noticed in the conceptualisation of terms between the students and the laymen could be explained. Since the students are more learned in the area of bio-medicine, they naturally possess the requisite knowledge, as discussed in Antia \& Ianna (2016: 75-76), to understand conceptual specification patterns (e.g., permissible intra-term relations) or conceptual characteristics of a specific discipline (or areas within a discipline) to determine how (i) items in multi-unit terms are combined, (ii) what items in such multi-unit terms tend to occupy what positions (initial, medial or final), and (iii) which terms (e.g., nucleus or head, determinants or modifiers) tend to be more reused, and so on.

\subsection{Translation and Discussion Exercise}

In Table 7, data obtained through the translation exercise are presented. Here, physicians were asked to provide Tiv translations of the names of the same diseases that were mentioned by the various groups that participated in our focus group discussions. This was done with a view to drawing similarities/differences with those features 
found in the conceptualisations/lexicalisations of the other groups.

It must be noted that the laymen were not involved in the translation exercise because they did not possess the required knowledge for understanding the structures of the components of the diseases to be translated.

Table 7. Physicians' Translations

\begin{tabular}{|c|c|c|}
\hline & Diseases & Tiv Translations \\
\hline 1. & Glaucoma & $\begin{array}{l}\text { Mnyoon u igbila } i \text { ken ashe } \\
\text { (pains in the eye nerves) }\end{array}$ \\
\hline 2. & Cataract & $\begin{array}{l}\text { Ishange } \\
\text { (a substance that covers part of the eye lens) }\end{array}$ \\
\hline 3. & Dilated Heart Disease & $\begin{array}{l}\text { Ishima i mulan ken imese } \\
\text { (enlargement of the heart by the left hand side) }\end{array}$ \\
\hline 4. & $\begin{array}{l}\text { Hypertrophic Heart } \\
\text { Disease }\end{array}$ & $\begin{array}{l}\text { Mmula u inyam i ken ishima } \\
\text { (swollen heart muscles) }\end{array}$ \\
\hline 5 . & $\begin{array}{l}\text { Restrictive Heart } \\
\text { Disease }\end{array}$ & $\begin{array}{l}\text { Mtaver u kpekpe u ishima } \\
\text { (stiffening of the heart walls) }\end{array}$ \\
\hline 6. & Jaundice & Angev mbu mlem (a sickness of the bile) \\
\hline 7. & Yellow Fever & Myamkyule (yellow fever) \\
\hline 8. & Gastric Ulcer & Avav shin uya (lesions in the large stomach) \\
\hline 9. & Duodenal Ulcer & $\begin{array}{l}\text { Avav sha gwarmya } u \text { kiriki } \\
\text { (lesions on the small intestine) }\end{array}$ \\
\hline 10. & AIDS & $\begin{array}{l}\text { Angev mbu wuan u shoji ken iyol } \\
\text { (sickness that kills antibiotics) }\end{array}$ \\
\hline
\end{tabular}

An analysis of the translations by the physicians will reveal a couple of things. One, there is high degree of convergence in their translations with the conceptualisations of the clinical students. For example, both groups rendered all the heart related diseases listed in numbers 3-5 of tables 6 and 7 in the same way. There is also a 
82 A Knowledge-based Approach in the Conceptualisation of Disease Terms in

noticeably higher level of precision and accuracy in the physicians' translations as compared to the laymen's and to some extent, preclinical students' conceptualisations that are generally characterised by vagueness and fuzziness. The laymen's terms and some of those by the pre-clinical students are very general while the specialists (physicians) demonstrated a high level of specificity in their translations though it could be noticed that the specialists' renderings were mostly based on either the literal meanings of the terms or on the basis of definitions. It may seem safe to conclude that the major reason for their higher level of precision in their renderings is as a result of their acquisition of specialist knowledge. The laymen on their part could not achieve such specificity because of their inability to decide whether a referent (disease) is a member of its extensional class or not, while the physicians as a result of their knowledge were able to do that.

Asked by the researcher whether they had comments on their translations especially as regards the congruity between the two languages involved (English and Tiv), their general comment was in the direction of the unavailability of Tiv terms to capture exactly what the English terms for concepts of diseases stood for. To have a better picture of the problems of congruity (among the groups interacted with), the researcher requested them to write out in English definitions of the diseases they have just translated. Below is what they produced.

Table 8. Definitions of Diseases by Physicians

\begin{tabular}{|c|l|l|}
\hline & \multicolumn{1}{|c|}{ Diseases } & \multicolumn{1}{c|}{ Definitions by Physicians } \\
\hline \hline 1. & Glaucoma & $\begin{array}{l}\text { A disease of the eye associated with increased } \\
\text { intraocular pressure and excavation and atrophy of } \\
\text { the optic nerve }\end{array}$ \\
\hline 2. & Cataract & Complete or partial opacity of the ocular lens \\
\hline
\end{tabular}




\begin{tabular}{|l|l|l|}
\hline 3. & $\begin{array}{l}\text { Dilated Heart } \\
\text { Disease }\end{array}$ & $\begin{array}{l}\text { When the heart (especially the left ventricle) is } \\
\text { enlarged and the pumping function limited causing } \\
\text { a loss of blood to the rest of the body }\end{array}$ \\
\hline 4. & $\begin{array}{l}\text { Hypertrophic } \\
\text { Heart Disease }\end{array}$ & $\begin{array}{l}\text { A genetic disorder caused by various mutations in } \\
\text { genes which causes the heart muscles to thicken and } \\
\text { which may obstruct blood flow and stops the heart } \\
\text { from working right }\end{array}$ \\
\hline 5. & $\begin{array}{l}\text { Restrictive } \\
\text { Heart Disease }\end{array}$ & $\begin{array}{l}\text { When the walls of the heart ventricles are stiff but } \\
\text { may not be thickened and resists filling of the heart } \\
\text { with blood }\end{array}$ \\
\hline 6. & Jaundice & $\begin{array}{l}\text { A yellowish staining of the integument, sclerae and } \\
\text { deeper tissues and of the excretions with bile } \\
\text { pigments which are increased in plasma }\end{array}$ \\
\hline 7. & Yellow Fever & $\begin{array}{l}\text { A tropical mosquito-borne viral hepatitis caused by } \\
\text { one of the yellow fever viruses }\end{array}$ \\
\hline 8. & Gastric Ulcer & An ulcer of the stomach \\
\hline 9. & Duodenal Ulcer & An ulcer of the small intestine \\
\hline 10. & AIDS & $\begin{array}{l}\text { Disorder of the immune system characterised by } \\
\text { opportunistic diseases, including candidiasis, } \\
\text { pneumonia, tuberculosis, etc. }\end{array}$ \\
\hline
\end{tabular}

These definitions given by the specialists could serve as a template to further analyse the conceptual divergences among the various groups. For instance, the laymen rendered both 'duodenal ulcer' and 'gastric ulcer' as avav a shin uya (wounds in the stomach) but the pre-clinical, clinical students and physicians conceptualised them differently: duodenal ulcer as: avav sha gwarmya u kiriki (lesions in the small intestine) and gastric ulcer as: avav sha gwarmya $u$ vesen (lesions in the large stomach). 
84 A Knowledge-based Approach in the Conceptualisation of Disease Terms in

\section{Conclusion}

This study sought to outline problems associated with conceptualisation of terms in Tiv and to point out the challenges associated with doing this. The challenges identified include (i) the special nature of the language of public health, and (ii) needed grounded knowledge in term conceptualisation activities. The study has underscored the point about attending to knowledge ontologies: a profoundly knowledge-intensive activity is needed to have an understanding of the distinctiveness of terms (diseases in this case). Scientific researches in any field of study seek to establish a maximum of certainty and control in the field of categorisation which leads to appropriateness. As seen in the use of terms by laymen and pre-clinical students, wrong conceptualisation and lexicalisation will lead to a dysfunctional communication among actors in hospitals. For instance, if these laymen present themselves before doctors and the two parties use medical terms with different concepts or meaning in mind they may be talking at cross-purposes. The language and terminology of health needs to be appropriate for all user groups. Here, appropriateness of terms is looked at beyond familiarity of terms but that the terms must carry some level of precision. One argument here may be the one in favour of evidencebased medical practice being more important than the narratives of the laymen but the truth is that in some areas, the health providers depend on what the patients say for diagnosis and prescription.

On the whole, the significance of this study lies in its addition to the body of literature in the area of health communication. The study has shown that what is required to avoid overextended conceptualisation is the need for knowledge creativity which will invite a thorough analysis of the characteristics of concepts to be 
designated. For instance, this will require a comparison at the level of concept systems and at the level of individual concepts in order to identify symmetries/asymmetries across languages: the language whose range is to be extended (Tiv in this case) and the language in which the disciplinary knowledge is more fully developed (English in this situation).

\section{References}

Antia, B. 2000. Terminology and Language Planning: An Alternative Framework of Practice and Discourse. Amsterdam: John Benjamins.

Antia, B. \& F. Bertin. 2004. Multilingualism and Healthcare in Nigeria: A Management Perspective. Communication and Medicine 1.2, 107-117.

Antia, B. \& O. Razum. 2012. HIV/AIDS Messaging in Germany and Nigeria: A Corpus Linguistics Study. Stellenbosch Papers in Linguistics PLUS 41, 1-23.

Antia, B. \& B. Ianna. 2016. Theorising Terminology Development: Frames from Language Acquisition and the Philosophy of Science. Language Matters 47.1, 61-83.

Crawford, P., B. Brown \& P. Nolan. 1998. Communicating Care: The Language of Nursing. Cheltenham: Stanley Thomes Publishers.

Ghaye, A. \& E. Robinson. 1989. Concept Maps and Children's Thinking: A Constructivist Approach. In F. Slater (ed.), Language and Learning in Teaching of Geography 115-139. London: Routledge.

Hammond, C. 2017. Politeness in Administrative Discourse: Some Perspectives from Two Institutions in Ghana. Journal of 
86 A Knowledge-based Approach in the Conceptualisation of Disease Terms in

Universal Language 18.1, 35-67.

Keally, J., C. Smith \& B. Winser. 2004. Information Empowers but Who Is Empowered? Communication \& Medicine 1.2, 119-129.

Kinchin, I., D. Hay \& A. Adams. 2000. How a Qualitative Approach to Concept Map Can Be Used to Aid Learning by Illustrating Patterns of Conceptual Development. Educational Research 42.1, 43-57.

Levin, M. 2006. Different Use of Medical Terminology and Culturespecific Models of Disease Affecting Communication Between Xhosa-speaking Patients and English-speaking Doctors at a South African Paediatric Teaching Hospital. SAMJ 96.10, 10801087.

Mintzes, J., J. Wandersee \& J. Novak. 1998. Teaching Science for Understanding: A Human Constructivist View. San Diego, CA: Academic Press.

Novak, J. 1998. Learning, Creating, and Using Knowledge: Concept Maps $(R)$ as Facilitative Tools in Schools and Corporations. Mahweh, NJ: Lawrence Erlbaum Associates.

Novak, J. \& D. Gowin. 1984. Learning How to Learn. Cambridge: CUP.

Payne, G. \& J. Payne. 2004. Key Concepts in Social Research. London/New Delhi: SAGE Publications.

Robinson, W. 1999. A View from the Science Education Research Literature: Concept Map Assessment of Classroom Learning. Journal of Chemical Education 76.9, 1179-1180.

Sager, J. 1990. A Practical Course in Terminology Processing. Amsterdam: John Benjamins.

Schmid, R. \& G. Telaro. 1990. Concept Mapping as an Instructional Strategy for High School Biology. Journal of Educational Research 84, 78-85. 
Soergel, D., T. Tse \& L. Slaughter. 2004. Helping Healthcare Consumers Understand: An "Interpretive Layer" for Finding and Making Sense of Medical Information. MEDINFO 2004, 931935.

Thagard, P. 1992. Conceptual Revolutions. Princeton: Princeton University Press.

Yassin, K. \& B. Antia. 2003. Quality Assurance of the Knowledge Exchange Process: A Factor in the Success of Child Health Programs in Developing Countries. International Journal of Health Care \& Quality Assurance 16.1, 9-19. 